Наносистели, нанолатеріали, нанотехнології Nanosistemi, Nanomateriali, Nanotehnologii 2019, т. 17, № 4, сс. 597-608 (c) 2019 ІМФ (Інститут металофізики ім. Г. В. Курдюмова НАН України) Надруковано в Україні. Фотокопіювання дозволено тільки відповідно до ліцензії

PACS numbers: 81.16.Pr, 83.80.Lz, 87.17.Uv, 87.19.Pp, 87.64.kv, 87.85.jj, 87.85.Rs

\title{
Gold Nanoparticles for Treatment of Experimental Burns
}

\author{
N. Volkova, M. Yukhta, and A. Goltsev \\ Institute for Problems of Cryobiology and Cryomedicine, \\ N.A.S. of Ukraine, \\ 23, Pereyaslavska Str., \\ 61015 Kharkiv, Ukraine
}

At present, among many types of nanoparticles, gold nanoparticles (AuNPs) are the most promising in biology and medicine due to the wide range of valuable chemical and physical properties. The goal of the present study is to investigate a possibility of cell-free application of the AuNPs in methylcellulose gel (MG) to treat full-thickness experimental burns in rats. Thermal burns of grade 3 are modelled in rats. The next day after the injury, the animals were randomly divided into three groups: control group without a treatment; research group 1 with application of MG; research group 2 with application of both MG and AuNPs (6 $\mu \mathrm{g} / \mathrm{ml})$. As shown, the superficial application of MG containing AuNPs improves the general status of animals, accelerates the wound-healing process by increasing cell proliferation and subsequent regulation of collagen synthesis/degradation. The results concerning the effect of AuNPs application in regenerative processes in burns provide some pre-conditions for the following advanced nanomedical-technology developments.

Нині, серед багатьох типів наночастинок, наночастинки золота (AuNPs) є найбільш перспективними в біології та медицині завдяки широкому спектру цінних хемічних і фізичних властивостей. Метою цього дослідження було вивчення можливости безклітинного використання AuNPs в метилцелюлозному гелі (MГ) для лікування глибоких експериментальних опіків. Термічні опіки 3-го ступеня моделювали на щурах. На наступний день після травми тварини випадковим чином були розділені на три групи: контрольна група без лікування; експериментальна група 1 із нанесенням МГ; експериментальна група 2 із застосуванням MГ й AuNPs (6 мкг/мл). Було показано, що поверхневе використання MГ, що містить AuNPs, поліпшувало загальний стан тварин, пришвидшувало процес загоювання ран за рахунок збільшення проліферації клітин і подальшої регуляції синтези/деградації колагену. Одержані тут результати впливу AuNPs на регенеративні процеси при опіках да- 
ють деякі передумови для подальшого розвитку наномедичних технологій.

Ныне, среди многих типов наночастиц, наночастицы золота (AuNPs) являются наиболее перспективными в биологии и медицине благодаря широкому спектру ценных химических и физических свойств. Целью настоящего исследования было изучение возможности бесклеточного использования AuNPs в метилцеллюлозном геле (МГ) для лечения глубоких экспериментальных ожогов. Термические ожоги 3-й степени моделировали на крысах. На следующий день после травмы животные случайным образом были разделены на три группы: контрольная группа без лечения; экспериментальная группа 1 с нанесением МГ; экспериментальная группа 2 с применением MГ и AuNPs (6 мкг/мл). Было показано, что поверхностное использование МГ, содержащего $\mathrm{AuNPs}$, улучшало общее состояние животных, ускоряло процесс заживления ран за счёт увеличения пролиферации клеток и последующей регуляции синтеза/деградации коллагена. Полученные тут результаты влияния AuNPs на регенеративные процессы при ожогах дают некоторые предпосылки для дальнейшего развития наномедицинских технологий.

Key words: gold nanoparticles, methylcellulose gel, experimental burns, regeneration.

Ключові слова: наночастинки золота, метилцелюлозний ґель, експериментальні опіки, регенерація.

Ключевые слова: наночастицы золота, метилцеллюлозный гель, экспериментальные ожоги, регенерация.

(Received 6 June, 2019; in final version, 10 June, 2019)

\section{INTRODUCTION}

In the years, a more intensive study of various new materials has been observed in science. This is primarily due to the rapid development of nanotechnology in general and nanomedicine in particular [1]. The close attention of researchers all over the world to nanotechnology is explained by the fact that the properties of nanosize materials differ sharply from these same substances in the ordinary state due to their increased relative surface area as well as due to the quantum size effect of nanoforms [2].

The use of nanomaterials and primarily nanoparticles of noble metals in the field of biomedicine has a great potential. Noble metals are unreactive and does not form complex with other elements that has find multiple applications including targeted drug delivery, protection against infection, cancer treatment and imaging. The small size of the nanoparticles cause their easily interact with 
biomolecules both at surface and inside cells, yielding better signals and target specificity for diagnostics and therapeutics [3].

Amongst many types of nanoparticles, gold nanoparticles (AuNPs) are the most important in biology and medicine due to the wide range of valuable chemical and physical properties [4], believing that they are acting as antioxidants due to their high catalytic activity and serving as a promising tool for reduction of inflammation. The possibility to use gold nanoparticles for the purposes of regenerative medicine is being considered too. In this field, the main function of AuNPs is assigned to the enhancing scaffolds properties, delivery efficiency and direct impact on cells differentiation. Thus, it has been demonstrated that AuNPs-chitosan composites enhanced proliferation of human fibroblasts in vitro in comparison with pure chitosan [5]. In recent study by Akturk et al. [6], it was shown that incorporation of AuNPs in collagen scaffolds enhanced the stability against enzymatic degradation and increased the tensile strength. These nanocomposites displayed also inhibition of the inflammatory and had a pronounced effect on skin tissue formation by increasing neovascularization and granulation tissue formation. Early, we also demonstrated that inclusion of AuNPs in the cryopreserved human fibroblasts enhances the regeneration of the skin by these cells in case of burns [7].

Although there is a multitude of studies related to the biomedical use of AuNPs as mentioned previously, only little is known about its potential in vivo effects such as induction/inhibition of inflammatory responses and possible contribution to the collagen synthesis by skin cells in the process of its regeneration. Therefore, in the present study, histoimmunological analysis was also performed to evaluate the role of AuNPs in methylcellulose gel (MG) on burn healing. It can be stated that the data in this area of research are still very limited. It was hypothesized that the inherent beneficial properties of AuNPs (good biocompatibility, antioxidant and antiinflammatory effects, contribution to the stimulation of proliferation of fibroblasts) might have a positive influence on the healing process of skin wounds when incorporated into MG. Thus, the aim of the present study was to investigate a possibility of cell-free using the AuNPs in methylcellulose gel (MG) to treat full-thickness experimental burns in rats.

\section{MATERIALS AND METHODS}

\subsection{Animals}

All the manipulations were carried out in a strict accordance with the requirements of the 'European Convention for the Protection of 
Vertebrate Animals used for Experimental and other Scientific Purposes'. The protocol was approved by the Committee on the Ethics of Animal Experiments of the Institute for Problems of Cryobiology and Cryomedicine of the National Academy of Sciences of Ukraine (Permit No. 2014-02).

The experiments were performed in 20 outbreed male white rats weighing $210 \pm 20 \mathrm{~g}$, which were housed in plastic cages (one animal per cage) and kept at normal conditions $\left(18-22^{\circ} \mathrm{C}, 30-70 \%\right.$ humidity, 12-hour lighting mode, standard diet with free access to food and water). The rats were acclimated for at least 7 days and were daily monitored for a health status during experiment. No adverse events were observed.

\subsection{Manipulations with AuNPs}

AuNPs were obtained by citrate synthesis [8] with an initial metal concentration of $45 \mu \mathrm{g} / \mathrm{ml}$. The average size of AuNPs was $15 \mathrm{~nm}$. AuNPs at a final concentration of $6 \mu \mathrm{g} / \mathrm{ml}$ were added to $1 \mathrm{ml}$ of MG.

\subsection{Study Design}

The scheme of the experiment is shown in Fig. 1.

Thermal burns grade 3 were modelled with a special stainless-

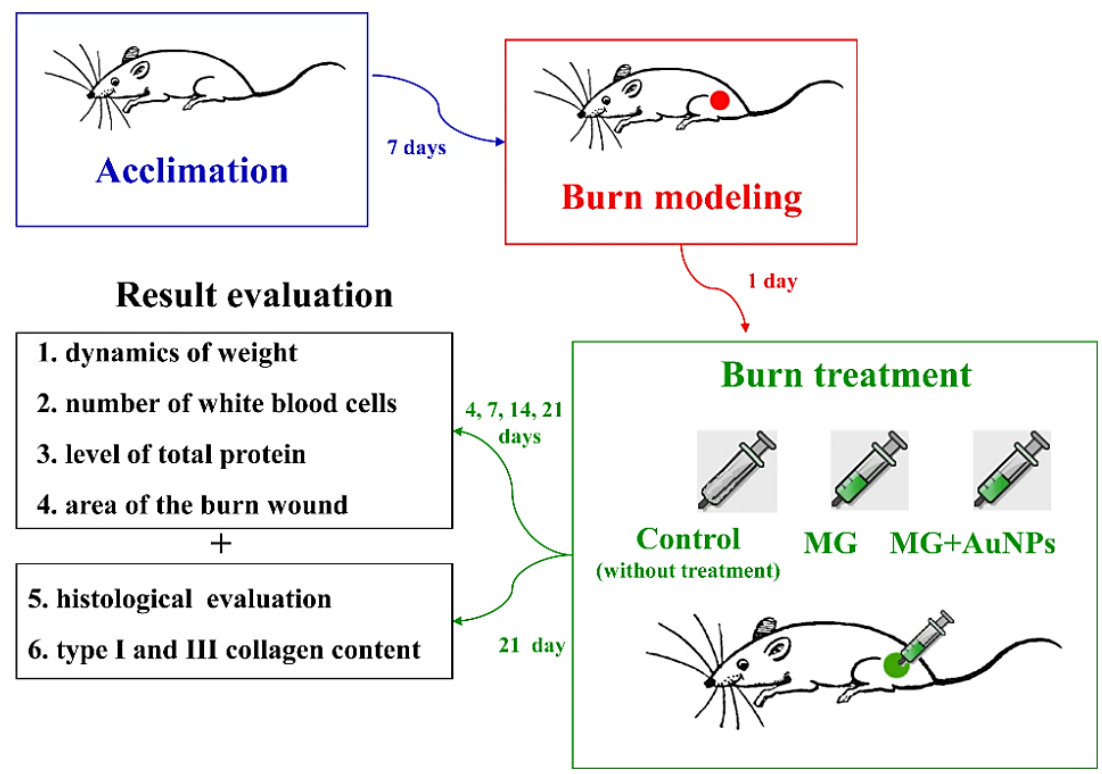

Fig. 1. Experimental scheme. 
steel device with a $5.4 \mathrm{~cm}^{2}$ operational area and equipped with a control thermometer [9]. For all the manipulations, the animals were anesthetized by an intraperitoneal injection of ketamine (10 $\mathrm{mg} / \mathrm{kg}$, Biolik, Kharkiv, Ukraine) and xylazine $(1 \mathrm{mg} / \mathrm{kg}$, Bioveta, Prague, Czech Republic). The hair over the left dorsal part of the back was shaved off and an applicator heated up to $100^{\circ} \mathrm{C}$ was applied to this area for $5 \mathrm{sec}$. During the 5-day postoperative period, the animals received ketofen $(2 \mathrm{mg} / \mathrm{kg}$, Merial SAS, Lyon, France) for anaesthesia.

The next day after the injury, the animals were randomly divided into three groups: control group $(n=5)$ with naturally occurred healing (without treatment); research group $1(n=5)$ with MG using on the burn surface; research group $2(n=5)$ with application of both MG and AuNPs $(6 \mu \mathrm{g} / \mathrm{ml})$ to a burn surface.

\subsection{General Animal Status Monitoring and Planimetric Study}

For all animals, a clinical observation was daily performed. On days 4, 7, 14 and 21 after the treatment, the animals were also weighed, the area of the burn wound was measured, and blood was taken from the tail vein to determine the number of white blood cells and the level of total protein.

Planimetric study of burns was performed by digital imaging method described in [10]. The number of white blood cells was determined on an automatic haematology analyser Mindray BC-3600 (Mindray, PRC).

The level of total protein were determined in serum of experimental animals on a RT-9200 semi-automatic analyser (Rayto, PRC) using Bio Systems (Spain) reagent kits.

\subsection{Histological Methods}

The rats were taken out from the experiment on day 21 after the treatment. The skin samples were fixed in $10 \%$ neutral formalin aqueous solution and coded by a third person, who was not involved in the experiment, to maintain the blinding. Serial paraffin sections of the skin $(4-5 \mu \mathrm{m})$ were stained with haematoxylin and eosin and investigated by microscope LSM 510 Meta (Carl Zeiss, Germany).

\subsection{Immunofluorescent Methods}

For assessment of types I and III collagen content in a cryostat, sections $(7-\mu \mathrm{m})$ of the skin were stained with monoclonal antibodies to type I collagen (1:2000, COL-1, Sigma-Aldrich, USA) with 
$\mathrm{CF}^{\mathrm{TM}} 488 \mathrm{~A}$ (Sigma-Aldrich, USA) and monoclonal antibodies to type III collagen (1:80, Millipore, USA) with goat anti-rabbit IgG Alexa Fluor ${ }^{\circledR} 647$ conjugate (Millipore, USA) according to the manufacturer's instructions. The fluorescent microscopy was performed with a laser-scanning microscope LSM 510 META (Carl Zeiss, Germany). Autofluorescence was quenched by $0.3 \mathrm{M}$ glycine solution (PAA, Austria) for $20 \mathrm{~min}$ [11].

\subsection{Statistical Analysis}

The Mann-Whitney U-criterion was used to determine the statistical significance of the differences in continuous variables when comparing between the groups with multiple (more than two) comparisons Kruskal-Wallis ANOVA tests using Excel (Microsoft, USA) and Statistics 8 (StatSoft, USA) software.

\section{RESULTS}

\subsection{General Animal Status}

The animals were daily monitored for a health status during whole investigating period, and adverse events were not observed. In intact animals, it was possible to note a gradual weight gain during the experiment, while in animals with burns this dynamics was smoothed out (Fig. 2,a). The control animals even lost some weight on the $7^{\text {th }}$ day after injury, and, as a result, they most of all lagged behind intact rats by weight at the end of the experiment.

The level of total protein in the serum of all animals with experimental burns had a similar dynamics at the early stages of the study. At first, this indicator sharply decreased on the $4^{\text {th }}$ day of monitoring, and then, it was slightly higher than the values of intact rats (Fig. $2, b)$. Later, a normalization of the level of total protein could be noted in research groups 1 and 2, while, in the control group, this indicator remained at a high level until the end of the experiment.

Modelling of a burn wound also provoked an increase in the number of white blood cells, but it should be noted that, in research group 1 and, especially, in group 2 , it was less pronounced, and to the $7^{\text {th }}$ day after therapy, this indicator returned to normal values (Fig. 2, c). In control animals, the number of white blood cells was normalized only on the $21^{\text {st }}$ day of experiment.

\subsection{Planimetric Results}

In the both research groups 1 and 2 , the burn wounds were clean, 

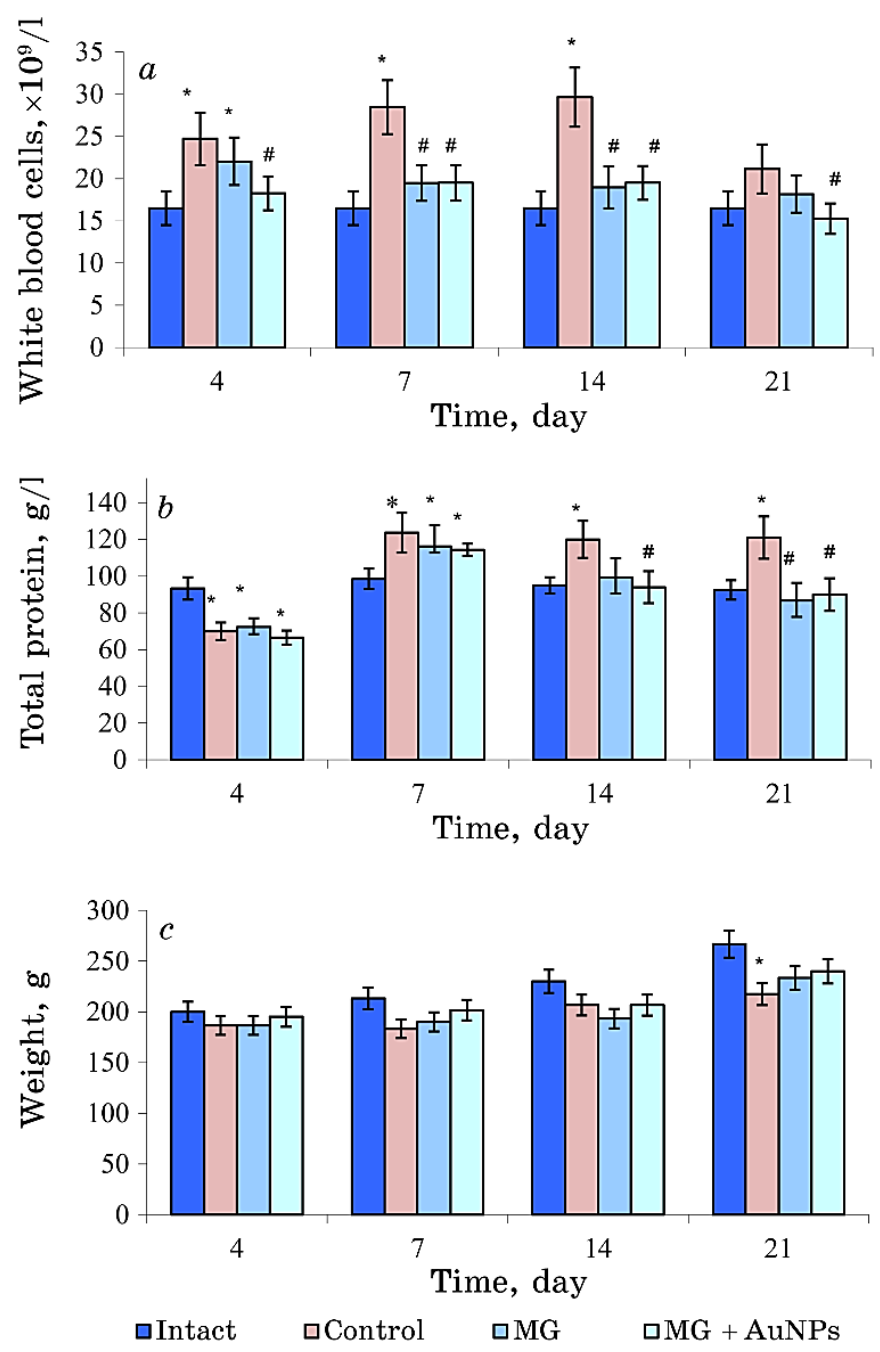

Fig. 2. Dynamics of general status indicators of experimental animals: $a-$ the body weight; $b$-the level of total protein; $c$-the number of white blood cells. *-the difference is statistically significant relative to the intact group; \#-the difference is statistically significant relative to the control $(M \pm m ; n=5 ; p<0.05)$.

with no signs of inflammation in contrast to the control group, where the burns were reduced due to the surface tension.

The area of burns in control decreased in dynamics with the lowest rate in comparison with experimental animals (Fig. 3). If we compare the research groups 1 and 2 with each other, it should be noted that burn wounds restored faster in case of MG with AuNPs 


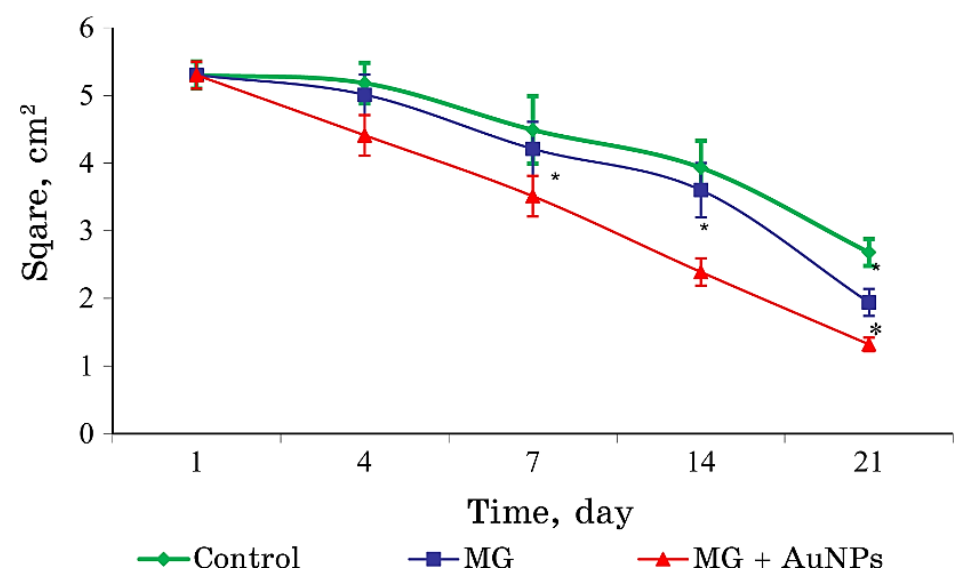

Fig. 3. Dynamics of the wound area in rats after therapy. *-the difference is statistically significant relative to the control $(M \pm m ; n=5$; $p<0.05)$.

application.

\subsection{Histological Studies}

The morphological assessment (Fig. 4) showed a typical layered skin structure of the intact group's rats. The skin of control animals on $21^{\text {st }}$ day of experiment had a signs of purulent burn wound; there was an intense lymphoid infiltration that held the formation of a granulation tissue. The morphological assessment of burn place in case of MG application showed a reduction in wound area and depth compared to the control. At the same time, lymphocytic infiltration of granulation tissue was moderately pronounced. These results showed a more intensive course of healing processes compared to the control. After AuNPs with MG application, a partial epithelization of burns was observed. The newly formed connective tissue was penetrated by microvessels, which are very important for wound healing due to the activation of regeneration. Thus, histologically, the healing rate after application of MG with AuNPs significantly exceeded one in the rest groups.

\subsection{The Average Square of Collagen Types I and III in Burn Wound}

Collagen fibres of types I and III are the main extracellular components of skin. The collagen of type III is actively synthesized by fibroblasts at the early stages of wound healing, type I collagen fibres 


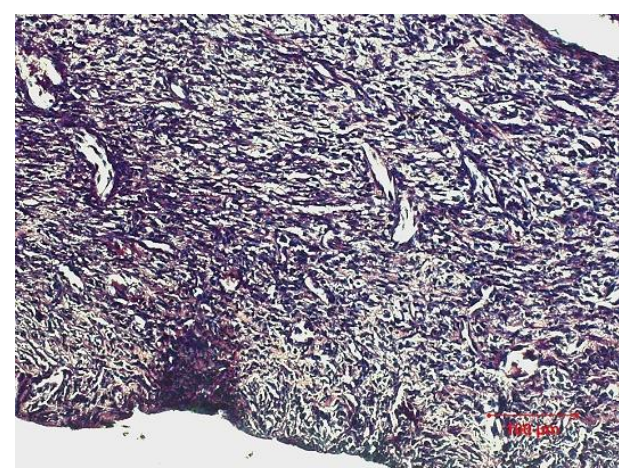

Intact

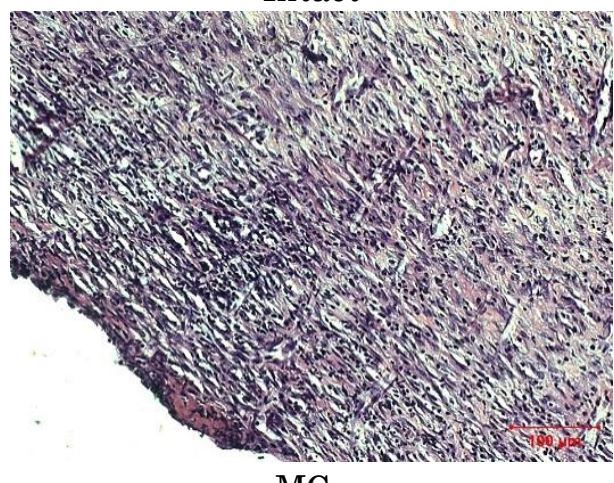

MG

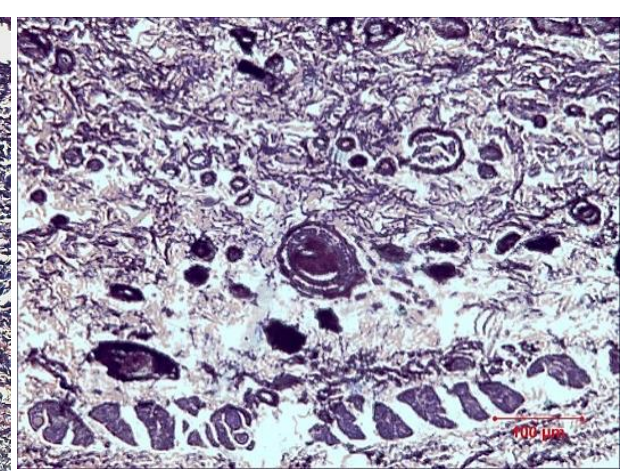

Control

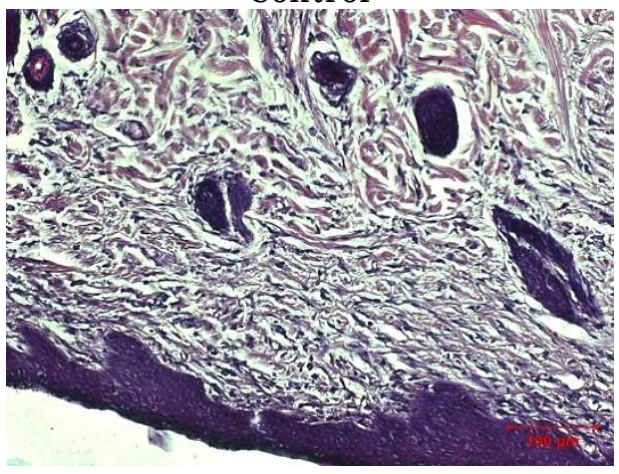

$\mathrm{MG}+\mathrm{AuNPs}$

Fig. 4. Burn wound of research group on 21 days. Hematoxylin and eosin staining.

in turn have high-strength properties and maintain mechanical properties of tissues.

Analysis of obtained results showed that type I collagen content in all groups after burn injury decreased and content of type III collagen on the contrary increased (Table). As a result, ratio of type I/type III collagens was significantly lower than in the intact group. But if compared research groups I (application of MG) and II (application of MG with AuNPs) with control, it can be noted that content of type I collagen within them was significantly higher in 1.26 and 1.58 times, respectively, without statistical differences in type III collagen content. This resulted in a lower decrease in the ratio of type I/type III collagens in research group, especially, after MG with AuNPs application. It is known that cell synthesis of various types of collagen in optimal proportions provides the adequate strength characteristics of tissues and prevents scar formation during wound healing. Thus, the use of MG with AuNPs promoted the restoration of the collagen ratio largely than using the MG sepa- 
TABLE. The average square of collagen of types I and III in burn wound of experimental animals on day 21 .

\begin{tabular}{c|c|c|c}
\hline & Collagen type I, \% & Collagen type III, \% & $\begin{array}{c}\text { Ratio of collagen } \\
\text { type I/type III }\end{array}$ \\
\hline Intact & $68.63 \pm 2.37$ & $15.1 \pm 2.18$ & $4.54 \pm 0.78$ \\
Control & $32.96 \pm 2.18^{*}$ & $30.25 \pm 4.72^{*}$ & $1.02 \pm 0.44^{*}$ \\
MG & $41.72 \pm 1.97^{*}$, \# & $27.78 \pm 3.28^{*}$ & $1.51 \pm 0.37^{*}$,\# \\
MG + AuNPs & $52.31 \pm 1.45^{*, \#}$ & $28.57 \pm 3.16^{*}$ & $1.83 \pm 0.56^{*, \#}$ \\
\hline
\end{tabular}

Note: *-the difference is statistically significant relative to the intact group; \#the difference is statistically significant relative to the control group $(M \pm m$; $n=5 ; p<0.05)$.

rately.

\section{DISCUSSION}

Burns are a global public health problem, accounting for an estimated 180000 deaths annually, the majority of which occur in lowand middle-income countries [12]. Non-fatal burn injuries present significant challenges in the functional and cosmetic repairs of patients. Large-area burns often lead to complications such as hypertrophic scarring, facial disfigurement, and loss of muscle and function.

One of the important tasks of treating patients with burns remains the rapid and full restoration of the skin. Tissue perfusion is of paramount importance to improve wound healing by bringing more nutrients and creating hyperoxia conditions suitable for healing. Effective wound dressings, which induce functional reconstruction following burn injury, would have a profound impact on patients with large area burns. The use of antioxidants in such dressings has attracted much attention. AuNPs were shown to have antioxidation effects, and so, it could be helpful in wound healing [13].

In our studies, it was shown that the superficial application of MG containing AuNPs improved the general status of animals (early normalization of the level of total protein and the number of white blood cells), accelerated the wound healing process (increased the rate of reducing the burn area) by increasing cell proliferation and subsequent regulation of collagen synthesis/degradation as well as alteration of types I and III collagen composition in the injury site.

Our results are consistent with data published by Leu et al. [14], which reported that topical AuNPs application together with other antioxidants significantly increased burn contraction rate, restored 
skin histological structure and regulated collagen synthesis/degradation. Thus, AuNPs contributed to the healing of the burns.

The obtained results of the effect of AuNPs application on regenerative processes in burns provide some pre-conditions for the following advanced bio- and nanotechnology developments.

\section{ACKNOWLEDGEMENT AND DISCLAIMERS}

The work was carried out with the support of the budget program of the National Academy of Sciences of Ukraine 'Support for the development of priority areas of scientific research' (code 6541230; the contract No. 92/19-H).

Nataliia Volkova declares that she has no conflict of interest. Mariia Yukhta declares that she has no conflict of interest. Anatoliy Goltsev declares that he has no conflict of interest.

\section{REFERENCES}

1. J. Shi, P. W. Kantoff, R. Wooster, and O. C. Farokhzad, Nat. Rev. Cancer., 17, No. 1: 20 (2017); doi: 10.1038/nrc.2016.108.

2. S. Salatin, S. Maleki Dizaj, and A. Yari Khosroushahi, Cell Biol. Int., 39, No. 8: 881 (2015); doi: 10.1002/cbin.10459.

3. M. Rai, A. P. Ingle, S. Birla, A. Yadav, and C. A. Santos, Crit. Rev. Microbiol., 42, No. 5: 696 (2016); doi: 10.3109/1040841X.2015.1018131.

4. M. Borzenkov, G. Chirico, M. Collini, and P. Pallavicini, Environmental Nanotechnology, Vol. 1 (Eds. N. Dasgupta, S. Ranjan, and E. Lichtfouse). Environmental Chemistry for a Sustainable World, Vol.14 (Cham, Switzerland: Springer: 2018), p. 343-390; doi: 10.1007/978-3-319-76090-2_10.

5. S. H. Hsu, Y. B. Chang, C. L. Tsai, K. Y. Fu, S. H. Wang, and H. J. Tseng, Colloids Surf. B: Biointerfaces, 85, No. 2: 198 (2011); doi: 10.1016/j.colsurfb.2011.02.029.

6. O. Akturk, K. Kismet, A. C. Yatsi, S. Kuru, M. E. Duymus, F. Kaya, M. Caydere, S. Hucumenoglu, and D. Keskin, J. Biomater. Appl., 31, No. 2: 283 (2016); doi: 10.1177/0885328216644536.

7. N. Volkova, M. Yukhta, O. Pavlovich, and A. Goltsev, Nanoscale Res. Lett., 11: 22 (2016); doi: 10.1186/s11671-016-1242-y.

8. L. A. Dykman, V. A. Bogatyrev, S. Yu. Shchyogolev, and N. G. Khlebtsov, Gold Nanoparticles. Synthesis, Properties, Biomedical Applications (Moscow: Nauka Publ.: 2008) (in Russian).

9. C. J. Busuioc, G. D. Mogoşanu, F. C. Popescu, I. Lascar, H. Parvanescu, and L. Mogoanta, Rom. J. Morphol. Embryol., 54, No. 1: 163 (2013).

10. R. Shetty, H. Sreekar, Sh. Lamba, and A. K. Gupta, Indian J. Plast. Surg., 45, No. 2: 425 (2012); doi: 10.4103/0970-0358.101333.

11. W. Baschong, R. Suetterlin, and R. H. Laeng, J. Histochem. Cytochem., 49, No. 12: 1565 (2001); doi: 10.1177/002215540104901210.

12. D. Adeloye, K. Bowman, K. Y. Chan, S. Patel, H. Campbell, and I. Rudan, 
J. Glob. Health., 8, No. 2: 021104 (2018); doi: 10.7189/jogh.08.021104.

13. S. Das and A. B. Baker, Front. Bioeng. Biotechnol., 31, No. 4: 82 (2016); doi: 10.3389/fbioe.2016.00082.

14. J. G. Leu, S. A. Chen, H. M. Chen, W. M. Wu, C. F. Hung, Y. D. Yao, C. S. Tu, and Y. J. Liang, Nanomedicine, 8, No. 5: 767 (2012); doi: 10.1016/j.nano.2011.08.013. 